\title{
Concreto com adição de borracha de pneu
}

\author{
Daniela Oliveira de Castro Batista ${ }^{1}$; Lucicledja Soares dos Santos²; Roberta Afonso Vinhal Wagner ${ }^{3}$ \\ 1, 2, 3 UNIUBE - Universidade de Uberaba \\ Daniela ocb@hotmail.com; Roberta.wagner@uniube.br
}

\section{1 - Introdução}

A construção civil é responsável por grande parte do lixo gerado nos centros urbanos. As pesquisas que visam o reaproveitamento de materiais, não somente os gerados pela construção civil, são muito importantes além de serem em benefício da sociedade fazem parte de uma conscientização que todos devem ter a respeito da sustentabilidade. $O$ pneu gera grandes problemas ao meio ambiente devido a dificuldade de seu descarte. De acordo com o instituto Akatu, um pneu leva 600 anos para se decompor. Em aterros eles costumam ficar dispostos, proporcionando assim a propagação de doenças. Diante da necessidade de reaproveitamento desse material, várias novas formas de utilização do mesmo já foram criadas e vários outros projetos de pesquisa estão em andamento. Ele já está sendo utilizado em calçadas, na pavimentação flexível, na fabricação de calçados, em contenções de talude como sapatas, no artesanato e até como objeto de decoração, dentre outros. Para seu uso em concreto, deve ser feita a separação do aço, do nylon e da borracha, que é o que iremos utilizar. Vamos substituir uma parte do agregado miúdo pela borracha triturada e vamos analisando qual a melhor porcentagem de substituição de agregado miúdo pela borracha atingirá ou ficará mais próximo do resultado esperado. Esperamos que este concreto sustentável seja utilizado em locais que não necessitem de uma resistência a compressão muito alta como calçadas e ciclovias.

A metodologia utilizada será o levantamento e descrição das tarefas e suas operações, designação das tarefas de cada um do grupo, leitura de livros e artigos publicados na internet, revistas sobre 0 assuntos que envolvam o tema, análise dos resultados obtidos através dos corpos de prova.

A reciclagem de pneus é uma forma de colaborar com o meio ambiente, e, é nosso dever tanto como profissionais como cidadãos propor soluções de reaproveitamento do lixo gerado. $O$ objetivo deste trabalho é desenvolver um traço de concreto inserindo o pneu como parte do agregado miúdo, e conseguindo atingir resistência à compressão e melhorar suas características como proporcionar conforto de seu usuário, como por exemplo a absorção de parte do impacto ao caminhar sobre o mesmo.

\section{2 - Materiais e métodos}

Os ensaios a serem realizados serão elaborados no laboratório da Universidade de Uberaba (UNIUBE), da cidade de Uberaba, Estado de Minas Gerais.

Os materiais a serem utilizados no experimento são:

- Cimento Portland - CPII-E32 devido ao baixo teor de adição, composto por escória de alto-forno rapidez de execução e redução de custos.

- Areia natural e brita.

- Resíduos de borracha de pneu triturado.

Os ensaios granulométricos serão feitos com os agregados baseados nas normas NBR - 7217. Os corpos de provas serão preparados com diferentes traços de acordo com a quantidade de borracha adicionada, serão testadas diferentes porcentagens de substituições do agregado miúdo por borracha triturada. Para os ensaios de aplicabilidade serão utilizados os moldes de corpos de provas de acordo com as normas.

Os corpos de provas que serão utilizados nos ensaios iniciais e finais serão rompidos com 7,14 e 28 dias.

\section{3 - Resultados e discussão}

Os resultados esperados são que este concreto sustentável possa ser utilizado em calçadas, ciclovias e em locais onde tenha apenas fluxo de pedestres e que não necessitem de uma resistência a compressão muito alta, e, devido a adição da borracha, o impacto gerado ao caminhar sobre o concreto seja menor que o concreto convencional. Esperamos também incentivar as pessoas de

www.uniube.br/entec - UNIUBE Campus Aeroporto - Uberaba/MG 
8을 EnTec - Encontro de Tecnologia da UNIUBE / 28 a 30 de outubro de 2014 seu uso e promover a conscientização da importância e da viabilidade de construções sustentáveis. Em conseqüência disso fazer do curso Luis César de Oliveira pelo apoio e com que, ao longo do tempo, o pneu triturado seja mais barato e mais acessível para o uso do mesmo em concreto e para outros fins.

\section{4 - Considerações finais}

O principal resultado esperado é que o concreto em estudo atinja a resistência a compressão de aproximadamente $20 \mathrm{MPa}$ e que apresente outras características que tornem seu uso viável. O projeto está em andamento e será desenvolvido através da iniciação científica.

\section{5 - Referências}

SILVA, Marina. Os pneus são um grave problema ambiental mundial. Disponível em:

http://www.eco21.com.br/textos/textos.asp?ID $=1407$. Acesso em: set. 2014 .

SANTOS, Altair. Pneu inservível viabiliza concreto sustentável, 2013. Disponível em: http://www.cimentoitambe.com.br/pneuinservivel-viabiliza-concreto-sustentavel/. Acesso em: set. 2014.

PETRUCCI, E.G.R. Concreto de Cimento Portland; Editora Globo, Porto Alegre, 10a ed.,1983

METHA, P.K. e Monteiro, P.J.M. Concreto: Estrutura, Propriedades e Materiais. Editora Pini Ltda, São Paulo, 1a ed., 1994.

SEGRE, N. C. Reutilização de borracha de pneus usados como adição em pasta de cimento, Tese de Doutorado Universidade Estadual de Campinas Instituto de Química, agosto/1999

\section{Agradecimentos}

Agradecemos à instituição Universidade de Uberaba pelo empréstimo de equipamentos e disponibilização de professores que nos auxiliam com 0 projeto de pesquisa. Agradecemos também à professora Roberta Afonso Vinhal Wagner por todo o apoio e incentivo que tem nos transmitido e ao gestor 